Estera Twardowska-Staszek

ORCID: 0000-0001-5499-7393

Akademia Ignatianum w Krakowie

I z a bela $Z$ ych

ORCID: 0000-0002-2962-0276

Uniwersytet w Kordobie, Hiszpania

\title{
Bullying i cyberbullying wśród dzieci i młodzieży. Analiza porównawcza wyników badań prowadzonych w Polsce \\ i Hiszpanii. Wyzwania dla profilaktyki
}

Bullying and Cyberbullying among Children and Adolescents: A Comparative Analysis of Research Projects Conducted in Poland and Spain. Challenges for Prevention

\begin{abstract}
ABSTRAKT
Artykuł prezentuje wyniki badań na temat zjawiska występowania bullyingu i cyberbullyingu wśród dzieci i młodzieży w Polsce i Hiszpanii. W pierwszej części artykułu dokonano charakterystyki zagadnienia, oprócz genezy i definicji terminów oraz omówienia natury zjawiska zwrócono uwage na negatywne konsekwencje, jakie pociqga za sobq tego rodzaju przemoc. W drugiej części artykułu przedstawiono wyniki badań dotyczqce rozpowszechnienia zjawiska na świecie oraz w Polsce. Na tym tle ukazano wyniki badań własnych.
\end{abstract}

SLOWA KLUCZOWE przemoc rówieśnicza, bullying, cyberbullying, analiza porównawcza, profilaktyka

\section{KEYWORDS}

peer violence, bullying, cyberbullying,

comparative analysis, prevention

SPI Vol. 22, 2019/3

ISSN 2450-5358

e-ISSN 2450-5366

DOI: 10.12775/SPI.2019.3.006

Nadestano: 27.06.2019

Zaakceptowano: 3.11.2019

Artykuły i rozprawy 
Celem przeprowadzonych badań jest porównanie rozpowszechnienia bullyingu i cyberbullyingu wśród uczniów szkół polskich i hiszpańskich. Dodatkowym zamiarem jest poznanie tendencji rozwojowych tego zjawiska w Polsce i Hiszpanii z uwzględnieniem wieku i płci osób badanych. Badania przeprowadzone zostały za pomoca międzynarodowych narzędzi badawczych. Analizie poddano 1052 uczniów szkół polskich oraz 1483 uczniów szkół hiszpańskich. Wyniki badań wskazuja, że skala zjawiska jest niepokojqco wysoka. W Polsce okoto $70 \%$ badanych uczniów bierze udział w bullyingu, a około $35 \%$ w cyberbullyingu. W Hiszpanii około $50 \%$ badanych uczniów bierze udział w bullyingu, a około $20 \%$ w cyberbullyingu. Wnioski zawieraja implikacje dla praktyki pedagogicznej. Profilaktyka i programy przeciwdziałajace tego rodzaju formom przemocy sq potrzebne i powinny być prowadzone w obu krajach.

\section{ABSTRACT}

This article shows the results of research focused on the phenomena of bullying and cyberbullying among Polish and Spanish children and adolescents. The first part of this article describes the characteristics of the topic, including genesis and definitions of terms and descriptions of the nature of the phenomena, highlighting the negative consequences of this kind of violence. The second part of this article describes different studies focused on bullying and cyberbullying across the world and in Poland. Against this background, the author's own research results are described.

The aim of this study is to compare the prevalence of bullying and cyberbullying among students enrolled in Polish and Spanish schools. An additional aim is to discover developmental tendencies in Poland and Spain whilst taking into account the age and gender of the participants. This research was conducted with the use of international measurement tools. The study included 1,052 Polish and 1,483 Spanish students. The results show that the prevalence of the phenomena is high. In Poland, around $70 \%$ of the participants are involved in some form of bullying and around $35 \%$ are involved in cyberbullying. In Spain, around 50\% of the participants are involved in a form of bullying and around $20 \%$ in cyberbullying. Conclusions include the implications for pedagogical practice. Prevention and intervention programs against this kind of violence are needed and should be conducted in both countries. 


\section{Wprowadzenie}

Przemoc rówieśnicza, a w szczególności jedna z jej najcięższych odmian - bullying to zjawisko rozpowszechnione niemal na całym świecie, którego konsekwencje dotykają wszystkich członków społeczności szkolnej (Zych, Ortega-Ruiz, Del Rey 2015a). Badania naukowe na temat bullyingu rozwijają się bardzo prężnie, dzięki czemu dysponujemy coraz obszerniejszą wiedzą dotyczącą rozpowszechnienia, uwarunkowań oraz konsekwencji tego zjawiska (Zych, Ortega-Ruiz, Del Rey 2015b). Jednocześnie obserwuje się potrzebę badań międzynarodowych na reprezentatywnych próbach dzieci i młodzieży pochodzących z różnych obszarów geograficznych. Niestety, liczba badań międzynarodowych, które pozwoliłyby zobaczyć polskich uczniów na tle rówieśników $z$ innych krajów, jest nadal niewystarczająca. Badania porównawcze, pomimo że są kosztowne i czasochłonne, pozwalają na stwierdzenie podobieństw lub różnic w zakresie badanego zjawiska. To z kolei pozwala na dokładniejszy opis interesującego nas fragmentu świata i inicjuje dalsze eksploracje badawcze.

Mając na uwadze skalę powyższego zjawiska, celem podjętych badań jest porównanie rozpowszechnienia bullyingu i cyberbullyingu wśród uczniów szkół polskich i hiszpańskich. Dodatkowym zamiarem jest poznanie tendencji rozwojowych na poziomie jednostek (wpływ wieku i płci) w Polsce i Hiszpanii.

\section{Bullying - charakterystyka zjawiska}

Termin bully został użyty w 1897 roku przez Fredrika L. Burka do opisu dzieci, które znęcały się nad słabszymi (por. Tłuściak-Deliowska 2017). Następnie w 1969 roku Peter-Paul Heinemann, szwedzki lekarz medycyny, opisał specyficzne zachowania chłopców na podwórku szkolnym, które nazwał mobbingiem ${ }^{1}$ (Roland, Auestad, Vaaland 2011). Kilka lat później szwedzki psycholog Dan Olweus opublikował badania dotyczące szkolnego mobbingu wśród chłopców w wieku preadolescencji (zob. Olweus 1973). Wkrótce potem, kolejny szwedzki psycholog, Anatol Pikas, napisał książkę

1 W pierwszych badaniach termin bullying stosowano w przypadku, gdy sprawcą był jeden uczeń, natomiast mobbing - gdy sprawcami była grupa uczniów. 
o tym, jak powstrzymać zjawisko przemocy wśród dzieci i młodzieży (Pikas 1976). Heinemann, Olweus i Pikas wywarli ogromny wpływ na rozwój badań dotyczących bullyingu w krajach skandynawskich. W późniejszych latach zaczęto interesować się tym zagadnieniem także w innych krajach, na przykład w Anglii (Rivers, Smith 1994) czy w Hiszpanii (Ortega 1997).

W języku polskim, podobnie jak w innych językach, nie ma jednego słowa, które odpowiada terminowi „bullying”, dlatego zarówno w języku potocznym, jak i naukowym używa się wielu synonimów, m.in. dręczenie, nękanie, znęcanie się, prześladowanie, zastraszanie, terroryzowanie, a także przemoc szkolna czy przemoc rówieśnicza. Nie wszystkie te określenia są zasadne i trafne, dlatego wielu autorów, zarówno polskich, jak i zagranicznych używa oryginalnego angielskiego terminu - bullying.

Bullying definiuje się jako przemoc szkolną/rówieśniczą, która polega na powtarzającym się i długotrwałym znęcaniu się niektórych uczniów nad wybranymi kolegami lub koleżankami ze szkoły (Smith, Cowie, Olafsson, Liefooghe 2002). Przy czym określenie „przemoc szkolna” odnosi się nie tylko do przestrzeni w sensie fizycznym, ale do osób zaangażowanych w zjawisko bullyingu, bowiem może ono mieć miejsce w budynku szkoły, jak również poza nią (w drodze do szkoły/domu, w miejscu zamieszkania czy w przestrzeni wirtualnej) (Komendant-Brodowska 2014). Innym, równie trafnym określeniem wydaje się być „przemoc rówieśnicza”, w której biorą udział osoby w zbliżonym wieku, z tego samego otoczenia, które pozostają w bezpośrednich relacjach i mogą wywierać na siebie odczuwalny wpływ (Rigby 2010).

Nie każdą przemoc szkolną/rówieśniczą można nazwać bullyingiem, bowiem charakteryzują go trzy specyficzne właściwości: intencjonalność, nierównowaga sił oraz powtarzalność. Pierwsza z nich, intencjonalność, związana jest z faktem, że celem sprawcy jest skrzywdzenie ofiary (Volk, Dane, Marini 2014). Zatem w takim przypadku mamy do czynienia $\mathrm{z}$ agresją. Jeśli dotyczy ona ucznia, który nie jest w stanie samodzielnie się obronić, to spełnione jest kolejne kryterium - nierównowaga sił pomiędzy sprawcą a ofiarą (Smith, Brain 2000). Warto zaznaczyć, że nierównowaga sił między uczniami może wynikać z kilku powodów. $Z$ jednej strony może dotyczyć siły fizycznej lub liczebności, z drugiej - cech osobowych 
sprawcy (Pyżalski 2012: 108). Jeśli dane zachowanie ma miejsce w sytuacji nierównowagi sił pomiędzy sprawcą a ofiarą, to mówimy o przemocy (Surzykiewicz 2000).

Biorąc pod uwagę różnorodne zachowania określane jako bullying, wyróżnia się różne jego typy: fizyczny (np. popychanie, szarpanie, kopanie, bicie), werbalny (np. przezywanie, ośmieszanie, obrażanie, plotkowanie) i relacyjny (np. ignorowanie, ostentacyjne oddalanie się, gdy ofiara podchodzi, wykluczanie z grupy, manipulowanie innymi w celu wrogiego zachowania wobec ofiary) (Pyżalski 2012: 109). Ponadto bullying może występować w formie bezpośredniej, w której konfrontacja odbywa się twarzą w twarz (np. popychanie, kopanie, obrażanie, znieważanie) oraz pośredniej, która ma miejsce za pośrednictwem innych osób (np. rozpowszechnianie plotek, namawianie innych uczniów do wykluczenia ofiary z grupy) (Rivers, Smith 1994).

Warto zauważyć, że w bullyingu uczniowie pełnią specyficzne role: sprawcy, ofiary oraz świadków. Ci pierwsi to osoby, które celowo i długotrwale stosują przemoc wobec uczniów słabszych, ci drudzy to uczniowie, którzy długotrwale doznają cierpienia i krzywdy. Pojawia się również cała struktura dominacji ze strony agresora i uległości ze strony ofiary (Ortega 2010). Dodatkowo niektórzy uczniowie przyjmują dwie role jednocześnie - sprawcy i ofiary.

Należy jednak pamiętać, że zjawisko bullyingu to nie tylko diadyczna interakcja między sprawcą (sprawcami) a ofiarą. Nie mniej ważne są osoby postronne, które są świadkami sytuacji i odgrywają istotną rolę w jego naturze i dynamice. Christina Salmivalli oraz jej współpracownicy wyróżnili cztery role, które przyjmują świadkowie bullyingu: 1) asystenci sprawcy, którzy dołączają się do agresora; 2) wzmacniacze sprawcy, którzy swoim zachowaniem (owacje, doping) nagradzają agresora; 3) outsiderzy, którzy nie reagują oraz 4) obrońcy ofiary, którzy stają po stronie dręczonego ucznia (Salmivalli, Lagerspetz, Björkqvist, Österman, Kaukiainen 1996). Bullying jest więc zjawiskiem grupowym, dzięki czemu często sprawcy zdobywają wysoki status społeczny.

Badania naukowe dotyczące zjawiska bullyingu rozwijają się niezmiernie szybko na całym świecie, jednocześnie wskaźniki rozpowszechnienia bullyingu wśród dzieci i młodzieży nadal są bardzo wysokie, a to pociąga za sobą poważne konsekwencje nie tylko dla ofiar i sprawców przemocy, ale także dla całej społeczności szkolnej. 
Ponadto w ostatniej dekadzie XXI wieku pojawiło się nowe zjawisko - cyberbullying, zwany także bullyingiem elektronicznym, bullyingiem cyfrowym, bullyingiem online. Przy czym należy zauważyć, że wielu autorów uważa, iż cyberbullying nie jest odrębnym zjawiskiem, a jedynie nową formą manifestacji bullyingu (zob. Menesini 2012). Sama nazwa owego zjawiska sugeruje, że jest to bullying realizowany za pomocą nowych technologii komunikacyjnych, zazwyczaj telefonów komórkowych czy internetu (Smith, Mahdavi, Carvalho, Fisher, Russell, Tippett 2008; Pyżalski 2012). Zagrożenie, jakie niesie za sobą to nowe zjawisko, jest niezwykle niebezpieczne z kilku powodów. Po pierwsze, skala używania smartfonów przez dzieci i młodzież ma tendencje wzrostową na całym świecie, dodatkowo wiek dzieci korzystających $z$ telefonów komórkowych i z internetu jest coraz niższy. Po drugie, $z$ dnia na dzień obserwujemy zmiany technologiczne, a wraz $\mathrm{z}$ nimi otwierają się nowe możliwości w zakresie usług oferowanych przez media społecznościowe. Tak więc coraz młodsze dzieci narażone są na zagrożenia, które - zanim zostaną zidentyfikowane i zbadane - mogą prowadzić do poważnych konsekwencji.

Dotychczasowe wyniki badań wskazują, że efektem bullyingu oraz cyberbullyingu są bardzo poważne krótko- oraz długoterminowe konsekwencje. Między innymi potwierdzono, że ofiary bullyingu nawet wiele lat po ukończeniu szkoły cechują się podwyższonym ryzykiem zachorowania na depresję (Ttofi, Farrington, Lösel, Loeber 2011a), natomiast wśród sprawców przemocy zauważa się większy wskaźnik zachowań przestępczych (Ttofi, Farrington, Lösel, Loeber 2011b). Inne konsekwencje bullyingu to zażywanie narkotyków (Ttofi, Farrington, Lösel, Crago, Theodorakis 2016), a także myśli i zachowania suicydalne (Van Geel, Vedder, Tanilon 2014).

\section{Rozpowszechnienie zjawiska bullyingu i cyberbullyingu na świecie}

Pierwsze badania dotyczące bullyingu zostały przeprowadzone w Skandynawii przez Olweusa. Niedługo potem media nagłośniły serię samobójstw wśród dzieci i młodzieży w różnych krajach, których przyczyny były przypisane właśnie przemocy rówieśniczej. Tego typu sytuacja miała miejsce w latach 80 . XX wieku m.in. w Norwegii, gdzie trzech nastoletnich chłopców popełniło samobójstwo 
w związku z byciem ofiarami zastraszania ze strony rówieśników. To zainicjowało stworzenie pierwszej kampanii społecznej przeciwko bullyingowi oraz rozwój badań naukowych w różnych obszarach geograficznych, które koncentrowały się nie tylko na opisie zjawiska, ale przede wszystkim na poszukiwaniu czynników ryzyka oraz czynników chroniących przed tego typu zachowaniami (Olweus, Limber 2010).

Metaanaliza dotycząca przemocy rówieśniczej z 80 badań z różnych stref geograficznych pokazuje, że średnie rozpowszechnienie zjawiska bullyingu oscyluje na granicy 35\% (36\% to ofiary przemocy, $35 \%$ - sprawcy przemocy). Rozpowszechnienie zjawiska cyberbullyingu jest nieco mniejsze, tj. 15\% to ofiary, 15\% - sprawcy (Modecki, Minchin, Harbaugh, Guerra, Runions 2014).

Jeśli chodzi o rozpowszechnienie zjawiska w różnych krajach, to w Chinach 2-66\% badanych deklaruje bycie ofiarą przemocy, natomiast 2-34\% - sprawcą (Chan, Wong 2015). Nieco mniejszy wskaźnik zjawiska oszacowano w Wielkiej Brytanii (33\% uczniów to ofiary, 11\% - sprawcy) (BIG 2015).

Z kolei Wendy Craig i jej współpracownicy porównali wskaźniki rozpowszechnienia przemocy w czterdziestu krajach. Według nich najniższymi wskaźnikami przemocy charakteryzowali się chłopcy w Szwecji, Republice Czeskiej i Hiszpanii oraz dziewczęta w Szwecji, Islandii i na Malcie. Najwyższymi zaś - chłopcy na Litwie, Łotwie i Estonii oraz dziewczęta na Litwie, Łotwie i Grenlandii (Craig, Harel-Fisch, Fogel-Grinvald i in. 2009). Najnowsze międzynarodowe badania na temat cyberbullyingu w ośmiu krajach europejskich (Bułgaria, Cypr, Francja, Grecja, Węgry, Włochy, Polska i Hiszpania) z 4847 uczestnikami pokazują, że najwyższy poziom przemocy rówieśniczej jest w Bułgarii i na Węgrzech, najniższy zaś w Hiszpanii (Sorrentino, Baldry, Farrington, Blaya 2019). Badania przeprowadzone w USA wskazują na stosunkowo wysokie wskaźniki w porównaniu do innych krajów zachodnich (Guerra, Williams, Sadek 2011).

\section{Rozpowszechnienie zjawiska bullyingu i cyberbullyingu w Polsce}

W Polsce prowadzane są liczne badania dotyczące skali agresji i przemocy wśród dzieci i młodzieży. Pomimo tego nadal potrzebne 
są badania, które dotyczyłyby konkretnie bullyingu i cyberbullyingu - jego skali, uwarunkowań i konsekwencji.

Jednym $\mathrm{z}$ większych projektów badawczych dotyczących zdrowia dzieci i młodzieży jest międzynarodowy program Health Behavior of School-Children (HBSC). Badania prowadzone są cyklicznie od 1983 roku. W początkowych badaniach HBSC temat agresji rówieśniczej nie był wiodący. Kwestionariusz ankiety zastosowanej w badaniach zawierał jedynie kilka pytań dotyczących stosowania przemocy oraz doświadczania przemocy. Obecnie, w najnowszych badaniach HBSC kierowanych w Polsce przez Joannę Mazur oraz Agnieszkę Małkowską-Szkutnik, pomiar bullyingu i cyberprzemocy jest realizowany na dużej grupie ( $\mathrm{n}=5225)$. Wyniki przeprowadzonych badań są następujące: sprawcami bullyingu jest 27,4\% badanej młodzieży, a ofiarami - 23,5\%. Najczęściej w bullyingu uczestniczyli uczniowie w wieku 13 lat (30,8\%), w porównaniu z 15-latkami (27\%) i 11-latkami (24,3\%). Tak więc nie obserwuje się tendencji wzrostowej ze względu na wiek. Jeśli chodzi o cyberprzemoc, wnioski są następujące: co piaty badany nastolatek był sprawcą $(16,2 \%)$, a co szósty ofiarą $(18,7 \%)$ cyberprzemocy przynajmniej jeden raz w ostatnich dwóch miesiącach. Zjawisko cyberprzemocy ma tendencje wzrostową w zależności od wieku badanych (Mazur, Małkowska-Szkutnik 2018).

Cykliczne badania dotyczące zachowań zdrowotnych młodzieży prowadzone są od 1984 roku. Badania mokotowskie (nazwa pochodzi od dzielnic szkół, w których je przeprowadzano), zainicjowane przez Barbarę Wołniewicz-Grzelak, a kontynuowane przez badaczy Instytutu Psychiatrii i Neurologii w Warszawie pod kierownictwem Krzysztofa Ostaszewskiego, koncentrują się przede wszystkim na zachowaniach ryzykownych młodzieży 15-letniej, a w szczególności na używaniu substancji psychoaktywnych. Przemoc rówieśnicza jest jedynie przyczynkiem do szerszego obrazu zachowań zdrowotnych młodzieży warszawskich szkół (zob. Pracownia Profilaktyki Mtodzieżowej „Pro- $M$ ”).

W ramach programu społecznego "Szkoła bez przemocy” od kil$\mathrm{ku}$ lat prowadzone są badania dotyczące przemocy szkolnej (2006, 2011). W badaniach z 2011 roku uczestniczyło 3169 uczniów, 883 nauczycieli oraz 2301 rodziców ze 150 szkół. Wyniki przeprowadzonych badań wskazują, że nie nastąpiły wyraźne zmiany w porównaniu do wyników badań z 2006 roku. Zaobserwowano jedynie wzrost 
skali przemocy werbalnej, relacyjnej oraz wymuszeń (z agresją werbalną spotyka się 63\% uczniów, natomiast z fizyczną aż ponad 30\%) (Giza-Poleszczuk, Komendant-Brodowska, Baczko-Dombi 2011).

W badaniach przeprowadzonych w 2012 roku przez Jacka Pyżalskiego 11,8\% uczniów szkół podstawowych i gimnazjów deklaruje bycie ofiarą bullyingu, 26,9\% - sprawcą, a 16,6\% - zarówno ofiarą, jak i sprawcą. W przypadku cyberbullyingu 6,6\% to ofiary, 19,6\% sprawcy, 5,9\% - ofiary/sprawcy (Pyżalski 2012).

W 2015 roku opublikowano wiele wyników badań dotyczących przemocy rówieśniczej wśród uczniów szkół polskich. Według badań Jakuba Kołodziejczyka i Bartłomieja Walczaka (2015) aż jedna trzecia uczniów deklaruje udział w bullyingu. Według Raportu Instytutu Badań Edukacyjnych „Bezpieczeństwo uczniów i klimat społeczny w polskich szkołach", co dziesiąty uczeń jest ofiarą bullyingu (Bezpieczeństwo uczniów i klimat spoteczny w polskich szkotach 2015). Z kolei wyniki badań dotyczących cyberbullyingu przeprowadzonych przez Rosarię Del Rey, José Casasa, Rosarię Ortega-Ruiz i ich wspólpracowników (2015) wskazują, że 6,1\% uczniów deklaruje bycie ofiarą, $6 \%$ - sprawcą, natomiast $4 \%$ to ofiary i sprawcy jednocześnie $(\mathrm{n}=900)$.

Kolejne badanie, przeprowadzone $\mathrm{z}$ wykorzystaniem kwestionariusza zaadaptowanego przez Pyżalskiego (2012) na grupie 1800 polskich nastolatków w wieku około 15 lat, dotyczyło cyberprzemocy. Uzyskane wyniki wskazują częstość występowania około 10-30\% w pozycjach dotyczących wiktymizacji i agresji (Tomczyk 2017).

$\mathrm{Na}$ wysokie wskaźniki zjawiska bullyingu w polskich szkołach wskazują także w swoich badaniach Izabela Zych, Rosaria Ortega-Ruiz i Vincente Llorent (2017). Według tych badaczy 18,7\% uczniów to ofiary, $13,1 \%$ sprawcy, a $44,1 \%$ ofiary/sprawcy. Najnowsze badania potwierdzają wysokie wskaźniki rozpowszechnienia zjawiska bullyingu i cyberbullyingu wśród polskich uczniów. Rezultaty badań wskazują, że 31\% uczniów to ofiary przemocy rówieśniczej, 6,5\% sprawcy, a 33\% ofiary/sprawcy. Jeśli chodzi o rozpowszechnienie cyberbullyingu, to $12,9 \%$ to ofiary cyberprzemocy, 5,2\% - sprawcy, a 15,2\% to ofiary/sprawcy (Twardowska-Staszek, Zych, Ortega-Ruiz 2018).

Zagadnienie przemocy rówieśniczej w nowatorski sposób pogłębiła Iwona Chmura-Rutkowska w swojej najnowszej książce 
Być dziewczyna, być chtopakiem i przetrwać. Pteć i przemoc w szkole w narracjach mtodzieży (2019). Autorka ukazuje problem przemocy ze względu na płeć, którą określa jako powtarzające się, intencjonalne krzywdzące zachowanie ze względu na przynależność do określonej płci. Przy czym w tym przypadku, podobnie jak w „tradycyjnym" bullyingu, także mamy do czynienia z nadużyciem i przewaga jednej osoby nad drugą. Według deklaracji uczniów ponad połowa badanych doświadcza codziennie lub prawie codziennie przemocy ze względu na płeć. Najczęstsza jest przemoc werbalna, ale także jej inne formy, jak np. fizyczna, psychiczna, relacyjna, materialna i seksualna. Przemoc ma miejsce w kontakcie bezpośrednim, ale coraz częściej dochodzi do niej pośrednio, za pomocą wiadomości SMS, MMS i komunikatorów internetowych (Chmura-Rutkowska 2019).

Powyższe dane pokazują, że problem przemocy rówieśniczej jest obecny niemal na całym świecie. Pomimo że badania na ten temat rozwijają się bardzo prężnie zarówno na świecie, jak i w Polsce, wciąż jest zbyt mało badań, które ujmowałyby zjawisko bullyingu i cyberbullyingu w perspektywie porównawczej. Potrzebne są badania międzynarodowe, w których wykorzystuje się te same wystandaryzowane narzędzia badawcze, co pozwala na porównanie uzyskanych rezultatów i szukanie wspólnego mianownika tych zjawisk.

\section{Opis postępowania badawczego}

Przedmiotem badań jest zjawisko bullyingu i cyberbullyingu wśród dzieci i młodzieży w Polsce i Hiszpanii. Głównym celem badań jest oszacowanie rozpowszechnienia zjawiska bullyingu i cyberbullyingu wśród uczniów szkół polskich i hiszpańskich. Dodatkowo wprowadzenie takich zmiennych, jak wiek i płeć badanych, pozwoli na analizę dynamiki tego zjawiska. Problem główny zawiera się w pytaniu: Jakie jest rozpowszechnienie zjawiska bullyingu i cyberbullyingu wśród dzieci i młodzieży w Polsce i Hiszpanii? Do przedstawionego wyżej głównego problemu badawczego sformułowano pytania szczegółowe: 1) Jakie jest rozpowszechnienie zjawiska bullyingu i cyberbullyingu wśród badanych? 2) Czy kraj jest czynnikiem różnicującym? 3) Jakie role przyjmują uczniowie biorący udział w bullyingu i cyberbullyingu? 4) Czy wiek jest czynnikiem różnicującym? 5) Jakie 
role przyjmują uczniowie biorący udział w bullyingu i cyberbullyingu? 6) Czy płeć jest czynnikiem różnicującym?

Niniejsze badania stanowią pierwszy etap szerszego projektu badawczego, który w swoim zamierzeniu będzie próbą poszukiwania predykatorów bullyingu i cyberbullyingu w kontekście takich zmiennych jak: empatia, empatia online, kompetencje emocjonalne, społeczne i moralne. Pozwoli to na identyfikację czynników ryzyka i czynników chroniących w zakresie wspomnianych zmiennych. Wyniki badań będą przyczynkiem do konstruowania programów profilaktycznych uwzględniających uzyskane rezultaty.

\section{Narzędzia badawcze}

Przeprowadzone badania mają charakter diagnostyczny, opisowy i porównawczy.

W prezentowanych badaniach zastosowano metodę pomiaru zmiennych nieobserwowalnych, a jako techniki badawcze zostały użyte testy psychologiczne. W obu krajach, w Polsce i Hiszpanii, badania przeprowadzono z wykorzystaniem narzędzi badawczych: The European Bullying Intervention Project Questionnaire (EBIP-Q) oraz The European Cyberbullying Intervention Project Questionnaire (ECIP-Q).

The European Bullying Intervention Project Questionnaire pozwala na drodze informacji pochodzących od ucznia (ofiara, agresor czy ofiara agresywna) w sposób wymierny określić rolę, jaką przyjmuje on w kontekście bullyingu szkolnego. Kwestionariusz składa się z 14 stwierdzeń diagnostycznych, 7 z nich dotyczy wiktymizacji (np. jakiś kolega/koleżanka mnie obraził; jakiś kolega/koleżanka mnie uderzył, kopnął albo mnie popchnął), kolejne 7 - agresji (np. obraziłem jakiegoś kolegę/koleżankę; uderzyłem, kopnąłem albo popchnąłem jakiegoś kolegę/koleżankę).

The European Cyberbullying Intervention Project Questionnaire jest samoopisowym narzędziem dotyczącym ról uczniów w cyberbullyingu (ofiara, agresor, ofiara agresywna). Kwestionariusz składa się z 22 itemów, 11 z nich dotyczy cyberwiktymizacji (np. ktoś mnie przeklinał albo obraził przez internet lub w wiadomościach wysyłanych telefonem komórkowym; ktoś rozpowszechniał plotki o mnie $\mathrm{w}$ internecie), 11 - cyberagresji (np. przeklinałem albo obraziłem 
kogoś przez internet lub w wiadomościach wysyłanych telefonem komórkowym; rozpowszechniałem plotki o kimś w internecie).

W obu kwestionariuszach badany ma za zadanie wskazać na pięciostopniowej skali częstotliwość, z jaką doświadczył poszczególnych sytuacji w minionym roku szkolnym. Skala ta zawiera następujące kategorie odpowiedzi: 1 - nigdy; 2 - tak, jeden albo dwa razy w ciągu roku; 3 - tak, jeden albo dwa razy na miesiąc; 4 - tak, około raz na tydzień; 5 - tak, częściej niż raz na tydzień.

Wyniki walidacji hiszpańskich wersji kwestionariuszy pokazują, że oba instrumenty mają dobre właściwości psychometryczne, co czyni je odpowiednimi narzędziami do diagnozy zjawiska. EBIP-Q: $a-$ Cronbacha $=0,84$ dla obu skal (zob. Ortega-Ruiz, Del Rey, Casas 2016), ECIP-Q: $\alpha$-Cronbacha $=0,97 \mathrm{w}$ przypadku cyberwiktymizacji, $\alpha$-Cronbacha $=0,93$ dla cyberprzestępczości (Del Rey, Casas, Ortega-Ruiz i in. 2015).

Prace nad polskimi wersjami kwestionariuszami przebiegały $\mathrm{w}$ dwóch etapach. W pierwszym dokonano tłumaczenia kwestionariuszy (z języka angielskiego na język polski [i z języka angielskiego na język polski] przez osobę mówiącą biegle w obu językach oraz przez tłumacza), w drugim określono trafność i rzetelność skal. Zarówno zbieżność językowa, jak i właściwości psychometryczne narzędzia okazały się dobre dla tej grupy badawczej. EBIP-Q- Satorra-Bentler Chi-square $=796.23, \mathrm{df}=76, \mathrm{NFI}=0.94, \mathrm{NNFI}=0.93$, $\mathrm{CFI}=0.94$, RMSEA $=0.09$ oraz współczynnik rzetelności a-Cronbacha: czynnik 1 (wiktymizacja) $\alpha=0,85$, czynnik 2 (agresja) $\alpha=0,85$. ECIP-Q: Satorra-Bentler Chi-square $=981.92, \mathrm{df}=208$, $\mathrm{NFI}=0.98, \mathrm{NNFI}=0.98, \mathrm{CFI}=0.98, \mathrm{RMSEA}=0.06$ oraz wspó1czynnik rzetelności $\alpha$-Cronbacha: czynnik 1 (cyberwiktymizacja) $\alpha=0.90$, czynnik 2 (cyberagresja) $\alpha=0.89^{2}$.

\section{Uczestnicy badań}

W pierwszej kolejności, w celu doboru jak najbardziej reprezentatywnej grupy badawczej, wysłano zapytania do dyrektorów kilkunastu

2 Szczegółowy opis polskiej walidacji obu kwestionariuszy oraz szczegółowa analiza nasilenia zachowań zawartych w obu narzędziach znajdują się w publikacji: Twardowska-Staszek, Zych, Ortega-Ruiz (2018). 
szkół o zgodę na przeprowadzenie badań wśród uczniów. Po uzyskaniu opinii nauczycieli oraz rodziców, dyrektorzy 8 szkół w Andaluzji i 6 szkół w Małopolsce wyrazili zgodę na przeprowadzenie badań. Badania były anonimowe, dobrowolne i przeprowadzone zgodnie z krajowymi i międzynarodowymi standardami etycznymi. Na początku wyjaśniono uczestnikom cele badań i poproszono o udzielenie szczerych odpowiedzi dotyczących poszczególnych zachowań w minionym roku szkolnym. Uczniowie mieli możliwość odmowy udziału w badaniu, jak również wycofania się w dowolnym momencie. Wszyscy wyrazili chęć wypełnienia kwestionariuszy. 26 uczniów nie odpowiedziało na zawarte w kwestionariuszach pytania, tak więc ich dane nie zostały wykorzystane w dalszych analizach. W Polsce badania zostały przeprowadzone przez Esterę Twardowską-Staszek z pomocą wyznaczonych przez dyrektorów szkół pedagogów, w Hiszpanii badania prowadziła Izabela Zych wraz z zespołem badawczym.

W Polsce w badaniach wzięło udział 1052 uczniów z sześciu szkół w województwie małopolskim (cztery szkoły z dużych miast, dwie z małych miast), 55\% uczniów ze szkół podstawowych $(n=580)$ oraz $45 \%$ uczniów z gimnazjum ( $\mathrm{n}=472)$. Wiek badanych wahał się od 9 do 16 lat $(\mathrm{M}=12.53, \mathrm{SD}=1.98)$, wśród badanych było 45\% chłopców $(\mathrm{n}=472)$ i 55\% dziewcząt $(\mathrm{n}=572)$.

W Hiszpanii grupę badawczą stanowiło 1483 uczniów z ośmiu szkół w Andaluzji (sześć szkół z dużych miast, dwie z małych miast), w tym 40,3\% uczniów szkół podstawowych ( $n=598$ ) i 59,7\% uczniów szkół gimnazjalnych $(\mathrm{n}=885)$. Wiek badanych wahał się od 9 do 16 lat $(\mathrm{M}=12.68, \mathrm{SD}=2.17), 48,1 \%$ dziewcząt i 51,9\% chłopców.

\section{Wyniki}

W pierwszej kolejności dokonano analizy udziału dzieci i młodzieży w zjawisku bullyingu w Polsce i Hiszpanii. 
Wykres 1. Zestawienie procentowe dotyczqce ról uczniów w zjawisku bullyingu w Polsce i w Hiszpanii

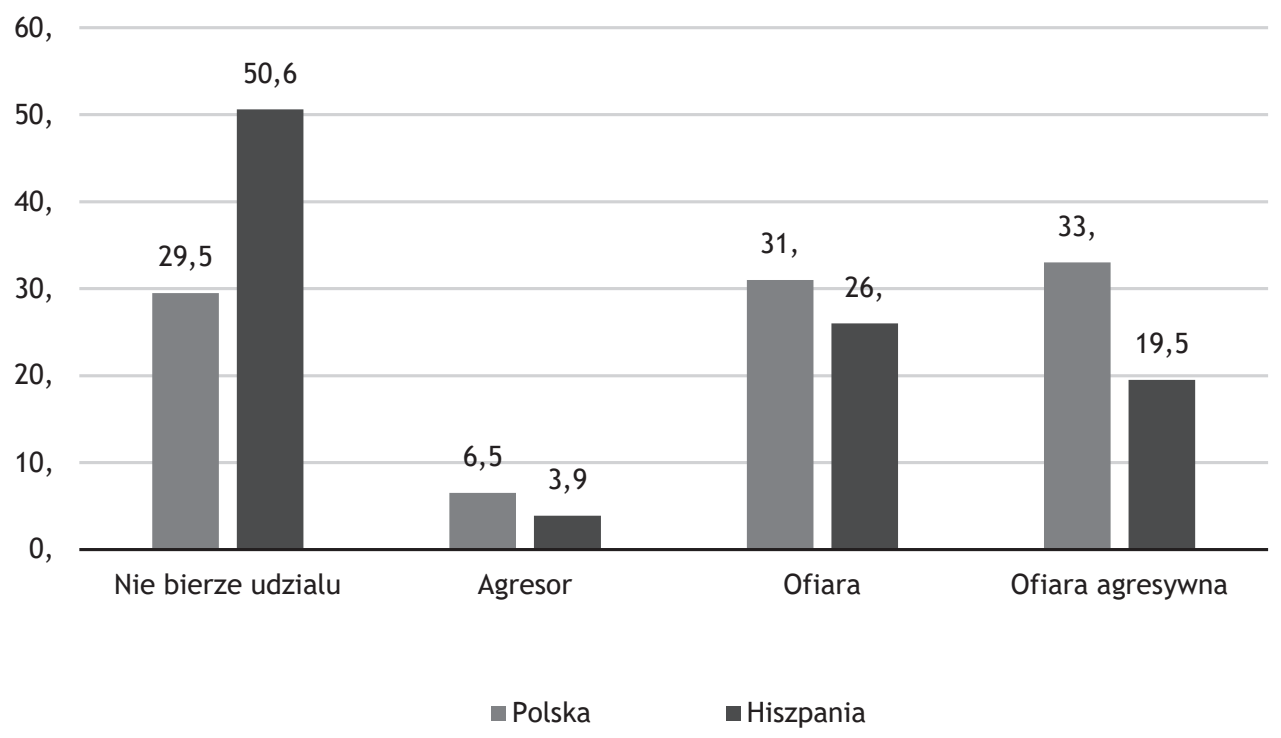

Źródło: Badania własne.

Otrzymane rezultaty badań jednoznacznie wskazują, że zjawisko bullyingu jest w znacznym stopniu rozpowszechnione wśród uczniów szkól polskich. Jedynie 29,5\% uczniów nie bierze udziału w bullyingu, pozostałe $70,5 \%$ to dzieci i młodzież, która podejmuje którąś z ról (31\% są to uczniowie, którzy deklarują, że w ciągu poprzedniego roku szkolnego doświadczyło zastraszania, 6,5\% uczniów przyznaje się do podejmowania zachowań agresywnych wobec innych uczniów, z kolei 33\% to osoby, które doświadczają zastraszania i jednocześnie są sprawcami tego typu zachowań). Zjawisko bullyingu jest również rozpowszechnione w Hiszpanii, chociaż jego skala jest mniejsza niż w Polsce. Wyniki pokazują, że 50,6\% tamtejszych uczniów nie bierze udziału w bullyingu, 3,9\% deklaruje bycie sprawcą przemocy, 26\% jest ofiarą, a 19,5\% - ofiarą agresywną.

Następny wykres prezentuje udział uczniów szkół polskich i hiszpańskich w zjawisku cyberbullyingu. 
Wykres 2. Zestawienie procentowe dotyczq̨ce ról uczniów w zjawisku cyberbullyingu w Polsce i w Hiszpanii

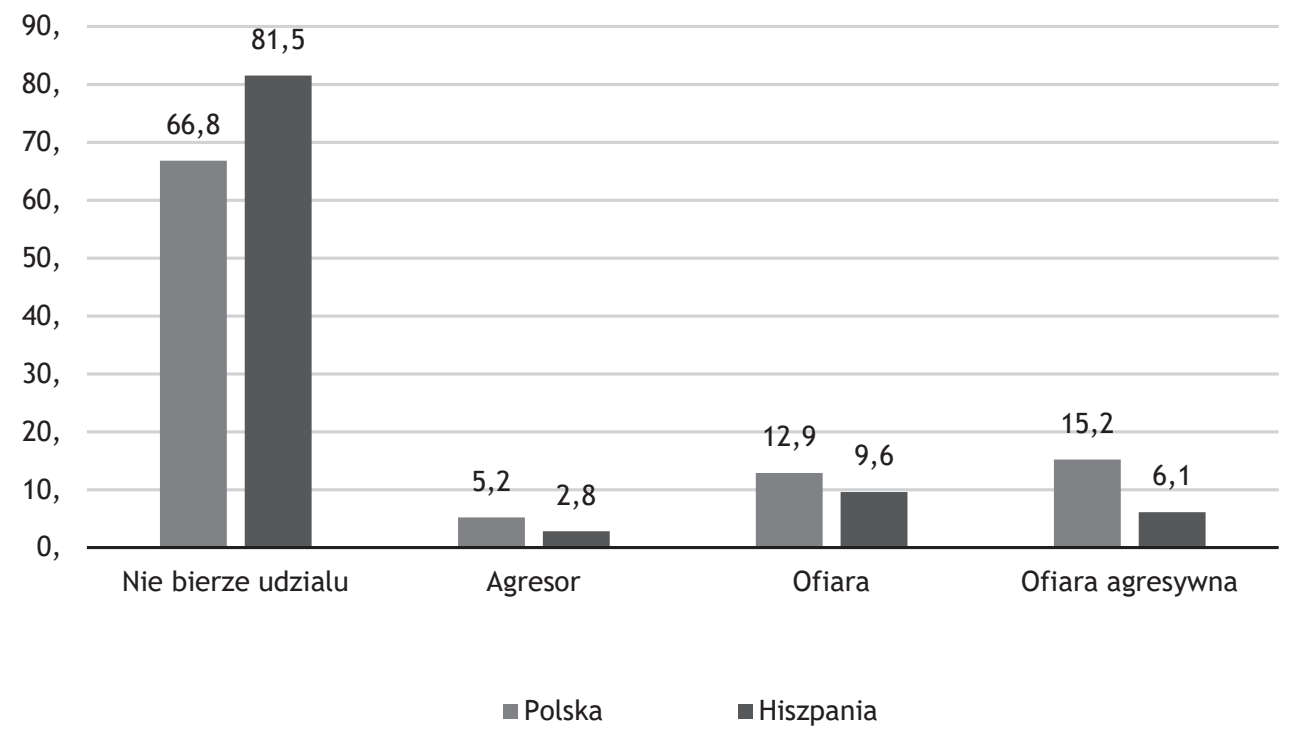

Źródło: Badania własne.

Otrzymane dane z Polski wskazują, że 66,8\% uczniów to osoby, które nie uczestniczą w cyberprzemocy. Wśród pozostałych osób $5,2 \%$ to sprawcy, $12,9 \%$ to ofiary, a $15,2 \%$ to uczniowie, którzy podejmują obie role. Podobnie jak w przypadku zjawiska bullyingu, cyberbullying jest również mniej rozpowszechniony w Hiszpanii. Wyniki pokazują, że 81,5\% tamtejszych uczniów nie bierze udziału w bullyingu, 2,8\% deklaruje bycie agresorem, 9,6\% ofiarą, a 6,1\% ofiarą agresywną.

W dalszej kolejności dokonano próby analizy dynamiki zjawiska, z uwzględnieniem wieku oraz płci badanych. 
Tabela l. Role przyjmowane przez uczniów w bullyingu i cyberbullyingu z uwzględnieniem wieku i płci uczniów szkół polskich i hiszpańskich

\begin{tabular}{|c|c|c|c|c|c|c|c|c|}
\hline & \multicolumn{2}{|c|}{$\begin{array}{c}\text { Szkoła podstawo- } \\
\text { wa }\end{array}$} & \multicolumn{2}{|c|}{ Gimnazjum } & \multicolumn{2}{|c|}{ Dziewczęta } & \multicolumn{2}{|c|}{ Chłopcy } \\
\hline & Polska & $\begin{array}{l}\text { Hiszpa- } \\
\text { nia }\end{array}$ & Polska & $\begin{array}{l}\text { Hiszpa- } \\
\text { nia }\end{array}$ & Polska & $\begin{array}{l}\text { Hiszpa- } \\
\text { nia }\end{array}$ & Polska & $\begin{array}{l}\text { Hiszpa- } \\
\text { nia }\end{array}$ \\
\hline \multicolumn{9}{|c|}{ Bullying } \\
\hline $\begin{array}{l}\text { Nie } \\
\text { bierze } \\
\text { udziału }\end{array}$ & $30,6 \%$ & $47,7 \%$ & $28,1 \%$ & $52,6 \%$ & $32,9 \%$ & $56,7 \%$ & $25,5 \%$ & $45 \%$ \\
\hline Agresor & $3,7 \%$ & $2,7 \%$ & $10 \%$ & $4,8 \%$ & $5,5 \%$ & $2,8 \%$ & $8 \%$ & $5 \%$ \\
\hline Ofiara & $39,3 \%$ & $29,1 \%$ & $20,9 \%$ & $23,9 \%$ & $37,5 \%$ & $27,8 \%$ & $22,7 \%$ & $24 \%$ \\
\hline $\begin{array}{l}\text { Ofiara } \\
\text { agre- } \\
\text { sywna }\end{array}$ & $26,4 \%$ & $20,5 \%$ & $41,1 \%$ & $18,8 \%$ & $24,3 \%$ & $12,6 \%$ & $43,8 \%$ & $25,9 \%$ \\
\hline \multicolumn{9}{|c|}{ Cyberbullying } \\
\hline $\begin{array}{l}\text { Nie } \\
\text { bierze } \\
\text { udziału }\end{array}$ & $80,4 \%$ & $87,1 \%$ & $51,1 \%$ & $77,6 \%$ & $69 \%$ & $82,1 \%$ & $64,2 \%$ & $81 \%$ \\
\hline Agresor & $2,4 \%$ & $1,6 \%$ & $8,5 \%$ & $3,7 \%$ & $5 \%$ & $2,3 \%$ & $5,5 \%$ & $3,2 \%$ \\
\hline Ofiara & $9,9 \%$ & $8,4 \%$ & $16,2 \%$ & $10,4 \%$ & $13,3 \%$ & $10,2 \%$ & $11,9 \%$ & $8,9 \%$ \\
\hline $\begin{array}{l}\text { Ofiara } \\
\text { agre- } \\
\text { sywna }\end{array}$ & $7,3 \%$ & $3 \%$ & $24,3 \%$ & $8,3 \%$ & $12,6 \%$ & $5,3 \%$ & $18,3 \%$ & $6,9 \%$ \\
\hline
\end{tabular}

Źródło: Badania własne.

Otrzymane rezultaty badań wskazują, że ofiarami bullyingu częściej padają uczniowie młodsi (ze szkół podstawowych), natomiast sprawcami i ofiarami agresywnymi częściej są uczniowie starsi (gimnazjum). Ponadto badania pokazują, że zjawisko cyberbullyingu nasila się wraz z wiekiem. Prawdopodobnie wynika to z faktu, że nie wszystkie dzieci w młodszym wieku szkolnym posiadają telefony komórkowe oraz nieograniczony dostęp do internetu. Dodatkowo młodsze dzieci podlegają większej kontroli zarówno ze strony rodziców, jak i nauczycieli. Jeśli chodzi o płeć, dziewczęta częściej są ofiarami, chłopcy natomiast częściej są sprawcami przemocy. Na podstawie uzyskanych danych nie stwierdza się istotnych różnic między płciami w odniesieniu do zjawiska cyberprzemocy. Wyniki polskie i hiszpańskie wskazują na podobne tendencje w obu krajach w kwestii znaczenia wieku i płci w zjawisku bullyingu i cyberbullyingu. 
Autorki mają świadomość pewnych ograniczeń przeprowadzonych badań, które wiążą się z doborem szkół, liczbą badanych, a także sposobem pomiaru. Konieczne byłoby przeprowadzenie szerzej zakrojonych badań w obu krajach, dobierając szkoły w sposób losowy, obejmując większą liczbę uczniów w różnych przedziałach wiekowych.

\section{Wnioski i wyzwania dla oddziaływań profilaktycznych}

Przegląd wyników badań międzynarodowych jednoznacznie wskazuje, że problem bullyingu i cyberbullyingu jest nadal aktualny wśród dzieci i młodzieży na całym świecie. Skala zjawiska, jak również brak wyraźnych tendencji spadkowych skłaniają do prowadzenia dalszych badań naukowych skoncentrowanych przede wszystkim na predykatorach przemocy rówieśniczej oraz skutecznych oddziaływaniach interwencyjnych i profilaktycznych.

Porównanie wyników badań uzyskanych przez uczniów w Polsce i Hiszpanii, a także ich ocena na tle innych krajów, pozwalają na wyciągnięcie wniosku o uniwersalnych mechanizmach przemocy rówieśniczej.

Zarówno w Polsce, jak i w Hiszpanii zjawisko bullyingu jest bardziej powszechne niż cyberbullyingu. Ofiarami częściej padają młodsi uczniowie i dziewczęta, agresorami częściej bywają starsi uczniowie i chłopcy. Obecne badania pokazują, że problem bullyingu i cyberbullyingu jest bardziej rozpowszechniony w Polsce niż w Hiszpanii. Jednym możliwym wytłumaczeniem jest to, że być może prowadzone w Hiszpanii i w innych krajach programy przeciwko bullyingowi i cyberbullyingowi doprowadziły do redukcji tego typu przemocy (Gaffney, Ttofi, Farrington 2019; Gaffney, Farrington, Espelage, Ttofi 2019). Zalecane jest zatem wprowadzenie nowych programów zapobiegawczych także w Polsce, które uwzględniłyby różnice wynikające z wieku i płci dzieci i młodzieży (zob. Barlińska, Szuster 2014).

Większość badań skupia się na rozpowszechnieniu zjawiska oraz identyfikacji czynników ryzyka i czynników chroniących przez przemocą. Niestety w większości są to badania przekrojowe i korelacyjne, które nie pozwalają w sposób dostateczny zbadać zależności między zmiennymi i odpowiedzieć na pytania o przyczyny i długoterminowe konsekwencje przyjmowania każdej ze wspomnianych ról. Niemniej 
jednak badania te są bardzo przydatne do opisania zmiennych związanych z zastraszaniem i próbą uwzględnienia ich $\mathrm{w}$ projektowaniu oddziaływań profilaktycznych.

Wyniki metaanalizy przeprowadzonej przez Davida Farringtona i Marię Ttofi (2009) wskazują, że programy interwencyjne i profilaktyczne mogą skutecznie ograniczyć zjawisko bullyingu. Skuteczne programy profilaktyczne są przede wszystkim kompleksowe, długoterminowe oraz intensywne. Kompleksowość oddziaływań powinna polegać na zaangażowaniu w program profilaktyczny nie tylko uczniów będących ofiarami i sprawcami bullyingu, ale także uczniów, którzy są obserwatorami zdarzeń. W tej optyce należy uwzględnić specyfikę czynników ryzyka oraz czynników chroniących w odniesieniu do ofiar, sprawców i świadków przemocy. Dodatkowo, podejmowane działania powinny mieć charakter nie tylko indywidualnej pracy $\mathrm{z}$ ofiarą lub sprawcą, ale $\mathrm{w}$ znacznej mierze winny mieć charakter zespołowy, obejmujący zespół klasowy oraz całą społeczność szkolną (kadrę zarządzającą, nauczycieli i pozostały personel szkoły). Nie bez znaczenia ma także zaangażowanie i współpraca ze strony rodziców. Jeśli chodzi o czas trwania programów profilaktycznych, to wyniki badań jednoznacznie wskazują, że oddziaływania długoterminowe i intensywne przynoszą najlepsze rezultaty (programy dla dzieci trwające 270 godzin lub dłużej, a dla nauczycieli minimum 4 dni okazywały się skuteczniejsze).

Przybliżając nieco bardziej działania zaradcze podejmowane na poziomie szkoły, należy szczególną uwagę zwrócić na konkretną politykę antybullyingową, m.in. tworzenie zespołów specjalistów zajmujących się diagnozą i przeciwdziałaniem przemocy rówieśniczej.

Dysponując coraz obszerniejszą wiedzą dotyczącą m.in. grup mniejszościowych, które częściej padają ofiarami przemocy rówieśniczej, można odpowiednio wcześniej zaplanować oddziaływania zapobiegające pojawieniu się problemu poprzez np. wyposażenie uczniów w niezbędną wiedzę, integrację zespołu klasowego oraz monitorowanie zachowań uczniów względem siebie i natychmiastowe reagowanie na pierwsze symptomy agresywnych zachowań.

$\mathrm{Na}$ poziomie szkoły istotnym czynnikiem chroniącym dzieci i młodzież przed niewłaściwymi zachowaniami jest klimat szkoły, poczucie bezpieczeństwa w szkole, świadomość wsparcia ze strony kolegów i koleżanek oraz nauczycieli. Niestety niektóre badania pokazują, 
że ponad połowa badanych uczniów wykazuje wysoki poziom nieprzystosowania szkolnego, na który składa się między innymi poczucie zagrożenia i obojętność ze strony innych (Twardowska-Staszek 2016). Istotnym elementem w oddziaływaniach profilaktycznych powinno być zatem wzmocnienie poczucia bezpieczeństwa w obszarze przestrzeni fizycznej (kontrola szatni, toalet, placu zabaw) oraz klimatu szkoły (jasny system norm klasowych i szkolnych).

Chociaż istnieje wiele opisanych modeli oddziaływań interwencyjnych i profilaktycznych zapobiegających i minimalizujących zjawisko bullyingu, to należy mieć na uwadze, że nie ma jednej cudownej metody, którą można zastosować w każdej szkole. W związku z tym, projektując oddziaływania profilaktyczne, należy uwzględniać konkretne potrzeby, warunki i kontekst danej szkoły.

\section{Bibiografia}

Barlińska J., Szuster A. (2014). Cyberprzemoc. O zagrożeniach i szansach na ograniczenie zjawiska wśród adolescentów, Warszawa: Wydawnictwa UW.

Chan H.C., Wong D.S.W. (2015). Traditional school bullying and cyberbullying in Chinese societies: Prevalence and a review of the whole-school intervention approach, „Aggression and Violent Behavior”, nr 23, s. 98-108, https://doi.org/10.1016/j.avb.2015.05.010.

Chmura-Rutkowska I. (2019). Być dziewczyna, być chtopakiem i przetrwać. Pteć i przemoc w szkole w narracjach mtodzieży, Poznań: Wydawnictwo Naukowe UAM.

Craig W., Harel-Fisch Y., Fogel-Grinvald H. i in. (2009). A cross-national profile of bullying and victimization among adolescents in 40 countries, „International Journal of Public Health”, t. 54, (Supplement 2), s. 216224. DOI: $10.1007 / \mathrm{s} 00038-009-5413-9$

Del Rey R., Casas J.A., Ortega-Ruiz R. i in. (2015). Structural validation and cross-cultural robustness of the European Cyberbullying Intervention Project Questionnaire, „Computers in Human Behavior”, t. 50, s. 141-147, https://doi.org/10.1016/j.chb.2015.03.065.

Farrington D.P., Ttofi M.M. (2009). School-based programs to reduce bullying and victimization, „Campbell Systematic Reviews”, nr 6, s. 1-148, <https://www.ncjrs.gov/pdffiles1/nij/grants/229377.pdf> [dostęp: 20.06.2019].

Gaffney H., Farrington D.P., Espelage D.L., Ttofi M.M. (2019). Are cyberbullying intervention and prevention programs effective? A systematic and meta-analytical review, „Aggression and Violent Behavior”, $\mathrm{nr} 45$, s. 134-153. DOI: 10.1016/j.avb.2018.07.002. 
Gaffney H., Ttofi M.M., Farrington D.P. (2019). Evaluating the effectiveness of school-bullying prevention programs: An updated meta-analytical review. „Aggression and Violent Behavior”, nr 45, s. 111-133. DOI: 10.1016/j. avb.2018.07.001.

Guerra N.G., Williams K.R., Sadek S. (2011). Understanding bullying and victimization during childhood and adolescence: $A$ mixed methods study, „Child Development”, t. 82, nr 1, s. 295-310. DOI: 10.1111/ j.1467-8624.2010.01556.x.

Kołodziejczyk J., Walczak B. (2015). Agresja i przemoc w Polskich szkotach: perspektywa socjoekologiczna, ,Ruch Pedagogiczny”, nr 1, s. 35-47.

Komendant-Brodowska A. (2014). Agresja i przemoc szkolna. Raport o stanie badań, Warszawa: Instytut Badań Edukacyjnych.

Mazur J., Małkowska-Szkutnik A. (red). (2018). Zdrowie uczniów w 2018 roku na tle nowego modelu badań HBSC, Warszawa: Instytut Matki i Dziecka.

Menesini E. (2012). Cyberbullying: The right value of the phenomenon. Comments on the paper "Cyberbullying: An overrated phenomenon?", „European Journal of Developmental Psychology", t. 9, nr 5, s. 544-552. DOI: 10.1080/17405629.2012.706449.

Modecki K.L., Minchin J., Harbaugh A.G., Guerra N.G., Runions K.C. (2014). Bullying prevalence across contexts: A meta-analysis measuring cyber and traditional bullying, "Journal of Adolescent Health”, t. 55, nr 5, s. 602-611. DOI: 10.1016/j.jadohealth.2014.06.007.

Olweus D. (1973). Hackkycklingar och översittare: Forskning om skolmobbning, Stockholm: Almqvist \& Wiksell.

Olweus D., Limber S.P. (2010). The Olweus bullying prevention program: Implementation and evaluation over two decades, [w:] S.R. Jimerson, S.M. Swearer, D.L. Espelage (red.), The handbook of school bullying: An international perspective, New York: Routledge, s. 377-402.

Ortega R. (1997). El proyecto Sevilla Anti-violencia Escolar. Un modelo de intervención preventiva contra los malos tratos entre iguales, „Revista de Educación", nr 313, s. 143-158.

Ortega R. (2010). Agresividad injustificada, bullying y violencia escolar, Madrid: Alianza Editorial.

Ortega-Ruiz R., Del Rey R., Casas J.A. (2016). Evaluar el bullying y el ciberbullying: Validación española del EBIP-Q y del ECIP-Q [Evaluation of bullying and cyberbullying: Spanish validation of EBIP-Q and ECIP-Q], „Psicología Educativa”, t. 22, nr 1, s. 71-79, https://doi.org/10.1016/j. pse.2016.01.004.

Pikas A. (1976). Slik stopper vi mobbing. (How to stop bullying), Oslo: Gyldendal.

Pyżalski J. (2012). Agresja elektroniczna i cyberbullying jako nowe ryzykowne zachowania mtodzieży, Kraków: Oficyna Wydawnicza „Impuls”. 
Rigby K. (2010). Przemoc w szkole. Jak jq ograniczyc??, przeł. R. Mitoraj, Kraków: Wydawnictwo UJ.

Rivers I., Smith P.K. (1994). Types of Bullying Behavior and Their Correlates, „Aggressive Behavior”, t. 20, nr 5, s. 359-368, https://doi.org/10.1002/ 1098-2337(1994)20:5<359::AID-AB2480200503>3.0.CO;2-J.

Roland E., Auestad, G., Vaaland G.S. (2011). Bullying, [w:] J. Pyżalski, E. Roland (red.), Bullying and Special Needs: A Handbook, Łódź: Wydawnictwo Wyższej Szkoły Pedagogicznej, s. 3-20.

Salmivalli C.,LagerspetzK.,Björkqvist K.,Österman K.,Kaukiainen A.(1996). Bullying as a group process: Participant roles and their relations to social status within the group, „Aggressive Behavior”, t. 22, nr 1, s. 1-15, https://doi. org/10.1002/(SICI)1098-2337(1996)22:1<1::AID-AB1>3.0.CO;2-T.

Smith P.K., Brain P. (2000). Bullying in schools: Lessons from two decades of research, „Aggressive Behavior”, t. 26, nr 1, s. 1-9. DOI: 10.1002/ (SICI)1098-2337(2000)26:13.0.CO;2-7.

Smith P.K., Cowie H., Olafsson R.F., Liefooghe A.P.D. (2002). Definitions of bullying: A comparison of terms used, and age and gender differences, in a fourteen-country international comparison, „Child Development”, t. 73, nr 4, s. 1119-1133. DOI: 10.1111/1467-8624.00461.

Smith P.K., Mahdavi J., Carvalho M., Fisher S., Russell S., Tippett N. (2008). Cyberbullying: Its nature and impact in secondary school pupils, ,Journal of Child Psychology and Psychiatry", t. 49, nr 4, s. 376-385. DOI: 10.1111/j.1469-7610.2007.01846.x.

Sorrentino A., Baldry A.C., Farrington D.P., Blaya C. (2019). Epidemiology of Cyberbullying across Europe: Differences between Countries and Genders, „Educational Sciences: Theory \& Practice”, t. 19, nr 2, s. 74-91. DOI: 10.12738/estp.2019.2.005.

Surzykiewicz J. (2000). Agresja i przemoc w szkole. Uwarunkowania socjoekologiczne, Warszawa: Centrum Metodyczne Pomocy Psychologiczno-Pedagogicznej.

Tłuściak-Deliowska A. (2017). Dręczenie szkolne. Spoteczno-pedagogiczna analiza zjawiska, Warszawa: Wydawnictwo APS.

Tomczyk L. (2017). Cyberbullying in 2010 and 2015: A perspective on the changes in the phenomenon among adolescents in Poland in the context of preventive action, „Children and Youth Services Review”, nr 75, s. 50-60. DOI: 10.1016/j.childyouth.2017.02.017.

Ttofi M.M., Farrington D.P., Lösel F., Loeber R. (2011a). Do the victims of school bullies tend to become depressed later in life? A systematic review and meta-analysis of longitudinal studies, "Journal of Aggression, Conflict and Peace Research", t. 3, nr 2, s. 63-73, https://doi. org/10.1108/17596591111132873.

Ttofi M.M., Farrington D.P., Lösel F., Loeber R. (2011b). The predictive efficiency of school bullying versus later offending: A systematic/meta-analytic 
review of longitudinal studies, „Criminal Behaviour and Mental Health”, t. 21, nr 2, s. 80-89. DOI: $10.1002 / \mathrm{cbm} .808$.

Ttofi M.M., Farrington D.P., Lösel F., Crago R.V., Theodorakis N. (2016). School Bullying and Drug Use Later in Life: A Meta-Analytic Investigation, „School Psychology Quarterly”, t. 31, nr 1, s. 8-27. DOI: 10.1037/ spq0000120.

Twardowska-Staszek, E. (2016). Zachowania ryzykowne mtodzieży szkolnej z niepetnosprawnościq intelektualna: uwarunkowania podmiotowe $i$ środowiskowe, Kraków: Akademia Ignatianum; Wydawnictwo WAM.

Twardowska-Staszek E., Zych I., Ortega-Ruiz R. (2018). Bullying and cyberbullying in Polish elementary and middle schools: Validation of questionnaires and nature of the phenomena, "Children and Youth Services Review”, nr 95, s. 2117-2225. DOI: 10.1016/j.childyouth.2018.10.045.

Van Geel M., Vedder P., Tanilon J. (2014). Relationship between peer victimization, cyberbullying, and suicide in children and adolescents: $A$ meta-analysis, „Jama Pediatrics”, t. 168, nr 5, s. 435-442. DOI: 10.1001/ jamapediatrics.2013.4143.

Volk A.A., Dane A.V., Marini Z.A. (2014). What is bullying? A theoretical redefinition, „Developmental Review”, t. 34, nr 4, s. 327-343, https://doi. org/10.1016/j.dr.2014.09.001.

Zych I., Ortega-Ruiz R., Del Rey R. (2015a). Scientific research on bullying and cyberbullying: Where have we been and where are we going, „Aggression and Violent Behavior”, t. 24, s. 188-198, https://doi.org/10.1016/j. avb.2015.05.015.

Zych I., Ortega-Ruiz R., Del Rey R. (2015b). Systematic review of theoretical studies on bullying and cyberbullying: Facts, knowledge, prevention, and intervention, „Aggression and Violent Behavior”, t. 23, s. 1-21, https:// doi.org/10.1016/j.avb.2015.10.001.

Zych I., Farrington D., Llorent V.J., Ttofi M.M. (2017). Protecting children against bullying and its consequences, New York: Springer.

Zych I., Ortega-Ruiz R., Llorent V.J. (2017). Nature and dynamics of peer violence in Polish upper secondary schools, „Social Psychology of Education”, t. 20, nr 2, s. 427-443. DOI: 10.1007/s11218-017-9378-x.

\section{Netografia}

Bezpieczeństwo uczniów i klimat spoteczny w polskich szkotach. (2015). <https:// www.ibe.edu.pl/p1/aktualnosci/525-przemoc-w-polskiej-szkole> [dostęp: 15.05.2019].

BIG. (2015). Bullying Intervention group: Current statistics August 2015, <https://www.bullyinginterventiongroup.co.uk/> [dostęp: 12.06.2016].

Giza-Poleszczuk A., Komendant-Brodowska A., Baczko-Dombi A. (2011). Przemoc w szkole. Raport z badañ. Maj 2011. Instytut Socjologii UW, <http://www.szkolabezprzemocy.pl/1391,przemoc-w-szkole-maj-2011> [dostęp: 15.05.2019]. 
Pracownia Profilaktyki Mtodzieżowej „Pro-M”, <http://www.ipin.edu.pl/? page_id=6565> [dostęp: 15.05.2019].

\section{ADRES DO KORESPONDENCJI}

Dr Estera Twardowska-Staszek

Akademia Ignatianum w Krakowie

Wydział Pedagogiczny

e-mail: estera.twardowska-staszek@ignatianum.edu.pl

Dr Izabela Zych

Universidad de Córdoba, España

Facultad de Ciencias de la Educación

e-mail: izych@uco.es 